\title{
TWO NEW SPECIES OF MEXICAN IRIDACEAE
}

\author{
Adolfo Espejo Serna \\ Ana Rosa López-FerRarI \\ Jacqueline Ceja Romero \\ Departamento Biología, C.B.S. \\ Universidad Autónoma Metropolitana \\ Unidad Iztapalapa \\ Apartado postal 55-535 \\ 09340 México, D.F. \\ e-mail: aes@xanum.uam.mx \\ AND \\ Anita Cholewa \\ University of Minnesota Herbarium \\ Bell Museum of Natural History \\ 1445 Gortner Ave. \\ St. Paul MN 55108 \\ U. S. A.
}

\begin{abstract}
Two new species of Iridaceae are described and illustrated, both collected in the state of Oaxaca, Mexico. Sisyrinchium planicola Ceja \& Cholewa has blue flowers with a white eye and grows abundantly in the flood plains of Llano de las Flores. Tigridia mariaetrinitatis Espejo \& López-Ferrari, only known from the type locality in Rancho Progreso, municipality of Chalcatongo de Hidalgo, belongs to the subgenus Hydrotaenia and has the flowers erect, brilliant yellow in their base, the outer tepals white lilac with purple spots and the inner tepals yellow with purple spots.
\end{abstract}

Key word: Iridaceae, Sisyrinchium, Tigridia, new species, Oaxaca, Mexico.

\section{RESUMEN}

Se describen e ilustran dos nuevas especies de Iridaceae, ambas colectadas en el estado de Oaxaca, México. Sisyrinchium planicola Ceja \& Cholewa sp. n. tiene flores azules con un ojo blanco y crece abundantemente en los sitios inundables del Llano de las Flores. Tigridia mariaetrinitatis Espejo \& López-Ferrari sp. n., sólo conocida de la localidad tipo en Rancho Progreso, municipio de Chalcatongo de Hidalgo, pertenece al subgénero Hydrotaenia y tiene las flores erectas, amarillas brillantes en la base con los tépalos externos blanco-liliáceos con manchas purpúreas y los tépalos internos amarillos con manchas purpúreas.

Palabras clave: Iridaceae, Sisyrinchium, Tigridia, nuevas especies, Oaxaca, México. 
The two most important genera of Mexican Iridaceae are undoubtedly Sisyrinchium and Tigridia. The former is represented in the country by 45 species (Ceja, Espejo \& LópezFerrari, 1998; Espejo \& López-Ferrari, 1996a, 1996b, 1997; Espejo, López-Ferrari \& Ceja, 1998, 1999), 56\% of the total species number (Goldblatt, 1990) and all known North American species of Tigridia are present in Mexico (Espejo \& López-Ferrari, 1996a, 1996b; Molseed, 1970).

While collecting for a study of Iridaceae in the state of Oaxaca, Mexico, specimens of Sisyrinchium and Tigridia were gathered and a careful review of material and pertinent literature indicates that there are two novelties for which we propose:

\section{Sisyrinchium planicola Ceja \& Cholewa sp. n. Fig. 1}

Herba perennis, erecta, 7-15(22) cm alta, radices fasciculatae, breves carnosaeque; folia omnia basalia, linearia, 0.8-1.5 mm lata; spathae subaequales, compressae; tepala patentia, $1.3-1.8 \mathrm{~cm}$ longa, $6-8 \mathrm{~mm}$ lata, elliptica vel oblongo-elliptica, caerulea, macula basali nivea; antherae atrocaeruleae, 3-3.5 mm longae; fructus obovoideus vel subsphaericus, $6 \mathrm{~mm}$ longus, $5.5 \mathrm{~mm}$ latus; semina ca. $1.5 \mathrm{~mm}$ diametro, dilute brunnea, umbonata, reticulata.

Erect perennial herb 7-15(22) cm high, esentially glabrous, roots tuberous, $0.9-1.8 \mathrm{~cm}$ long, $0.2-0.4 \mathrm{~cm}$ in diameter; flowering stem straight to slightly curved, slightly compressed and minutely scaberulous especially in the upper portion, distally branching; basal leaves 5-8, linear, 4-11 cm long, 0.8-1.5 mm wide, acute, glabrous except for the minutely scaberulous margin; cauline leaves none except for the modified bracteal ones subtending flowering branches; peduncles slightly compressed, 0.5-2.5 cm long; spathes containing 15-flowered rhipidia, compressed, subequal, $1.5-2.3 \mathrm{~cm}$ long, 5-7 mm wide, the outer usually shorter, membranous margins of the outer spathe hyaline or reddish; pedicels erect, 2.1$2.6 \mathrm{~cm}$ long, surpassing the spathe for $0.2-1.2 \mathrm{~cm}$; flowers light blue-purple with a white eye, 2.6-3.6 cm diameter, tepals spreading horizontally from the base, obovate to oblongelliptic, 1.3-1.8 cm long, 6-8 mm wide; filaments 4-4.5 mm long, basally connate for 1-1.5 mm; anthers linear, 3-3.5 mm long, deep blue; ovary glabrous, oblong-ellipsoid, $2.5 \mathrm{~mm}$ long, ca. $1.6 \mathrm{~mm}$ in diameter, style $5 \mathrm{~mm}$ long, stigma capitate, yellow; fruit obovoid to subglobose, $6 \mathrm{~mm}$ long, $5.5 \mathrm{~mm}$ diameter; seeds subglobose, ca. $1.5 \mathrm{~mm}$ in diameter, light brown, umbonate, testa reticulate.

TYPE: México. Oaxaca, Distrito Ixtlán de Juárez, Municipio San Juan Atepec, Llano de las Flores, sobre la carretera Tuxtepec-Oaxaca, $2970 \mathrm{~m}$ s.n.m., Ilanos inundables, 7.VIII.1998. A. Espejo, A. R. López-Ferrari \& J. Ceja 6000 (holotype UAMIZ; isotypes ENCB, IEB, MINN)

S. planicola (Fig. 2) is clearly distinct from other species with blue flowers because of its small size and the large light blue purple flowers that almost resemble the flowers of Nemastylis, a small genus of ca. 5 species of bulbous Iridaceae distributed from southwestern U.S.A. to Guatemala. The non-apiculate tepals and the style dividing shortly above the base into two long filiform branches, each slightly swollen at the stigmatic area, 
Espejo et al.: Two New Species of Mexican Iridaceae

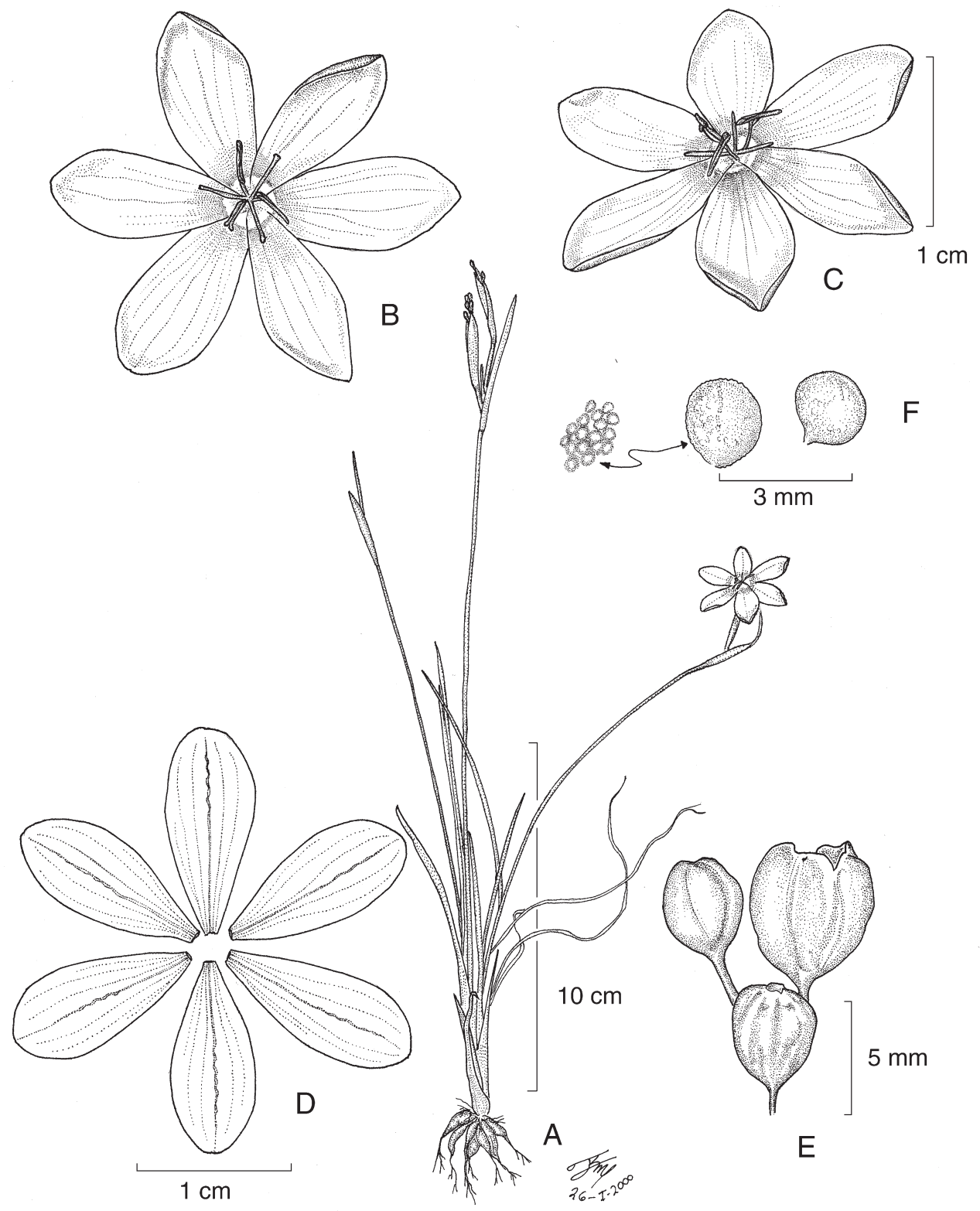

Fig. 1. Sisyrinchium planicola Ceja \& Cholewa. A. Habit; B, C. Flower; D. Flower dissected; E. Capsules; F. Seeds. 
are also distinctive. S. planicola is similar in vegetative morphology to S. johnstonii Standl. and probably confused with it in herbarium material. However the analysis of the floral structure allows the clear delimitation of both species. In $S$. planicola the flowers are light blue-purple with the tepals extended and rounded at the apex while $S$. johnstonii has white to blue campanulate flowers with the tepals apiculate. The name of the species refers to the type locality, the flood plains of Llano de las Flores, Oaxaca.

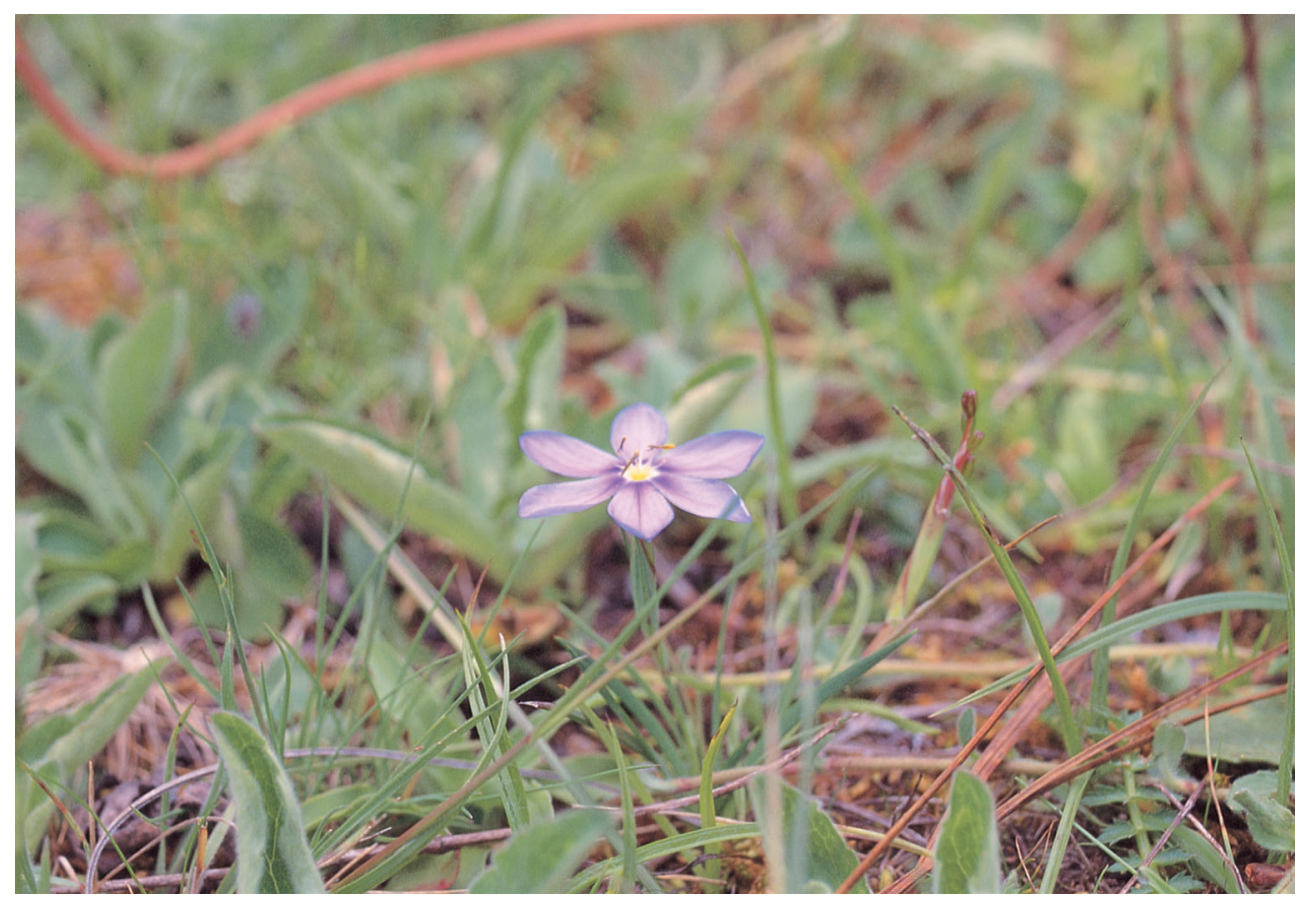

Fig. 2. Sisyrinchium planicola Ceja \& Cholewa in its natural habitat.

Tigridia mariaetrinitatis Espejo \& López-Ferrari sp. n. Fig. 3

Herba perennis, erecta, bulbosa, caules usque $40 \mathrm{~cm}$ alti; folia basalia dua, linearia, plicata, usque ad $57 \mathrm{~cm}$ longa et $4 \mathrm{~mm}$ lata; spathae bractearum subaequales, $6-8 \mathrm{~cm}$ longae; flores erecti, 5-6 cm diametro; tepala conniventia et ad basim cupulam vivide luteam formantia; tepala externa elliptica vel oblongo-elliptica, $2.6-3 \mathrm{~cm}$ longa, $1.5-1.8 \mathrm{~cm}$ lata; alba vel albo-lilacina, maculis purpureis, tepala interna deltoideo-unguiculata, ca. $1 \mathrm{~cm}$ longa, $1.2 \mathrm{~cm}$ lata, lutea, maculis purpureis; glandes ad tepalorum partem apicalem positae; filamenta connata, ca. 7-9 mm longa; antherae lineares, $9 \mathrm{~mm}$ longae; styli ramuli 6-7 mm longi. 
Espejo et al.: Two New Species of Mexican Iridaceae

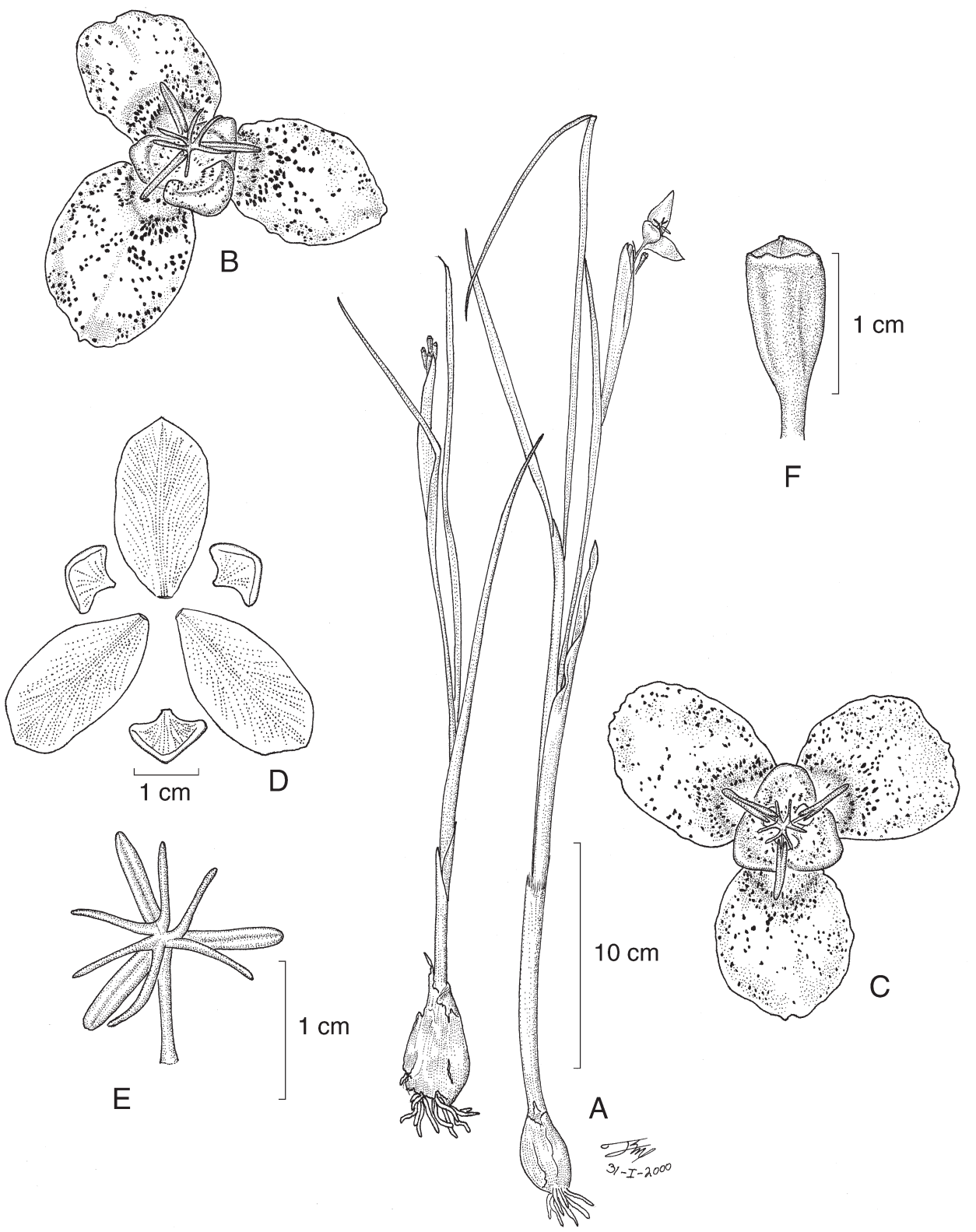

Fig. 3. Tigridia mariaetrinitatis Espejo \& López-Ferrari. A. Habit; B, C. Flower; D. Flower dissected; E. Anthers and style detail; F. Immature capsule. 
Erect bulbous perennial herb $25-40 \mathrm{~cm}$ high, glabrous, bulb ovoid to amply ovoid, to $5 \mathrm{~cm}$ long, $1.8-3 \mathrm{~cm}$ wide, the outer tunics thin, pale brown; basal leaves two, linear, plicate, $25-57 \mathrm{~cm}$ long, $4 \mathrm{~mm}$ wide, longer than the flowering stem, cauline leaf one, linear, plicate, to $25 \mathrm{~cm}$ long, $4 \mathrm{~mm}$ wide; flowering stem to $40 \mathrm{~cm}$ high, branched just above the cauline leaf; inflorescence a rhipidium with the spathes subequal, $6-8 \mathrm{~cm}$ long, ca. $1 \mathrm{~cm}$ wide, conduplicate, acute; peduncles $1.8-6 \mathrm{~cm}$ long, sulcate; pedicels linear-filiform, 4-8 cm long; flowers $4-8$ by rhipidium, erect, $5-6 \mathrm{~cm}$ diameter, the tepals connivent at base forming a shallow cup, spreading distally, the base brilliant yellow, outer tepals white to white-lilac with purple spots, elliptic to oblong-elliptic, acuminate, $2.6-3 \mathrm{~cm}$ long, $1.5-1.8 \mathrm{~cm}$ wide, inner tepals yellow with purple spots, deltoid-unguiculate, ca. $1 \mathrm{~cm}$ long, $1.2 \mathrm{~cm}$ wide, without a spreading limb, glands disposed at the apical part of the inner tepals, semicircular; filaments connate for 7-9 mm, anthers linear, ca. $9 \mathrm{~mm}$ long; ovary oblong, ca. $6 \mathrm{~mm}$ long, ca. $3 \mathrm{~mm}$ wide, style branches 6-7 mm long, deeply bifid into two arms, red to purple; mature capsule turbinate, $1.8-2.2 \mathrm{~cm}$ long, ca. $1 \mathrm{~cm}$ diameter; seeds subglobose to pyriform, ca. $3 \mathrm{~mm}$ in diameter.

TYPE: México. Oaxaca, Distrito Tlaxiaco, municipio Chalcatongo de Hidalgo,

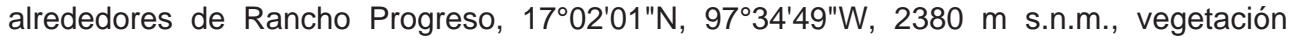
secundaria, abundante en las milpas, 26.VI.2000. A. Espejo, A. R. López-Ferrari, J. Ceja y A. Mendoza Ruiz 6247 (holotype UAMIZ; isotypes GH, IEB, K, MEXU, MINN, OAX).

Paratype: México. Oaxaca, Distrito Tlaxiaco, Municipio Chalcatongo de Hidalgo, 300 $\mathrm{m}$ al oeste de la agencia municipal de Rancho Progreso, ca. 2520 m s.n.m., vegetación secundaria, 30.VI.1996. A. Mendoza Ruiz 150 (CIIDIR, IEB, UAMIZ).

T. mariaetrinitatis is only known from the type locality and occurs in seasonally flooded plains with secondary vegetation at 2380-2520 m alt. (Fig. 4). The name of the species honors María Trinidad Serna Treviño, mother of the senior author.

The new species belongs to Tigridia subgenus Hydrotaenia (sensu Molseed, 1970) and to the vanhouttei complex ( $T$. alpestris Molseed, $T$. bicolor Molseed, $T$. ehrenbergii (Schltdl.) Molseed, T. galanthoides Molseed, T. hallbergii Molseed, T. molseediana Ravenna and T. vanhouttei (Baker) Espejo \& López-Ferrari) because of the following features. Tepals occur in two series of markedely unequal length, the inner ones ovate to orbicular, without a spreading limb, rounded at the base, and with a very small claw. The inner tepals and gland shape of $T$. mariaetrinitatis most closely resemble those of $T$. hallbergii and $T$. bicolor, however the former has pendulous flowers and $T$. bicolor differs from the species here proposed in the size and color of flowers.

\section{ACKNOWLEDGMENTS}

We thank Jerzy Rzedowski and Graciela Calderón de Rzedowski for critically reading the manuscript and Rolando Jiménez Machorro for the original illustrations used here. 


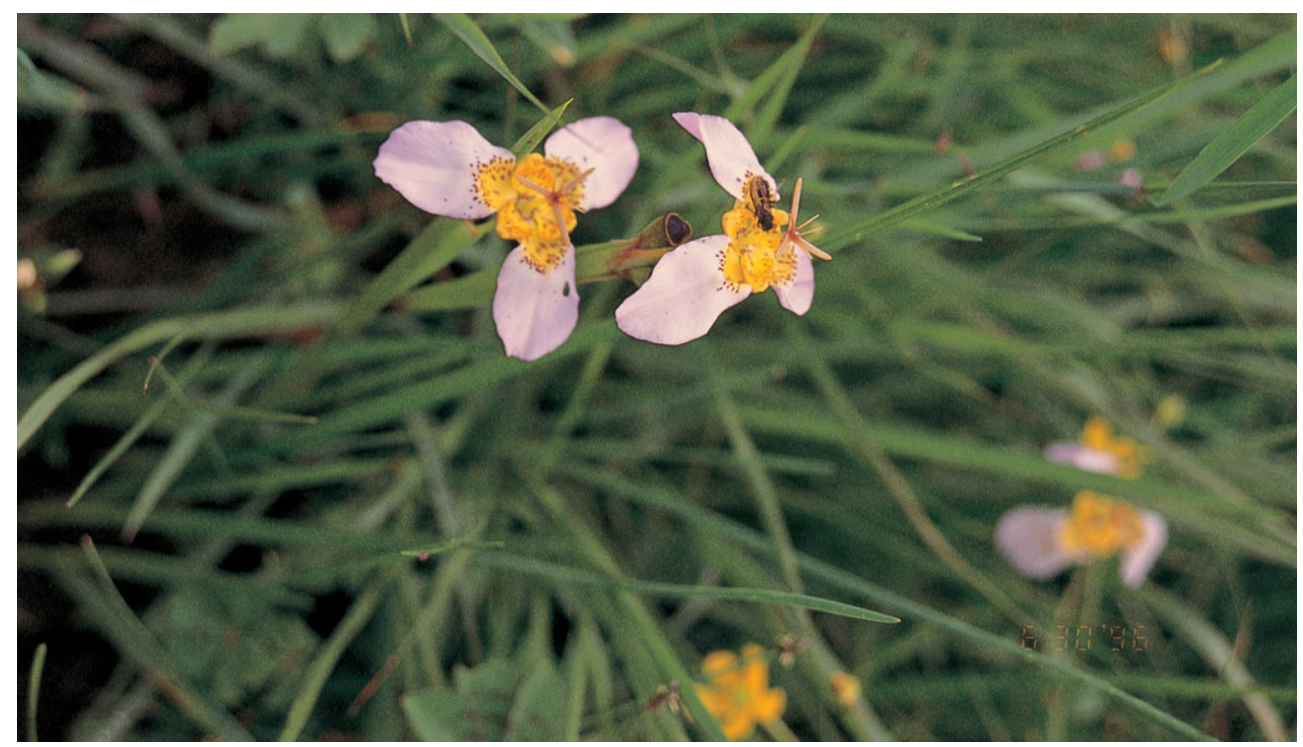

Fig. 4. Tigridia mariaetrinitatis Espejo \& López-Ferrari in its natural habitat.

\section{CITED LITERATURE}

Ceja, J., Espejo, A. \& A. R. López-Ferrari. 1998. Sisyrinchium arguellesiae (Iridaceae, Sisyrinchieae) una nueva especie del estado de Querétaro. Acta Bot. Mex. 44: 87-91.

Espejo, A. \& A. R. López-Ferrari. 1996a. Las monocotiledóneas mexicanas, una sinopsis florística. 1. Lista de referencia. Parte VI. Dioscoreaceae a Nolinaceae. Consejo Nacional de la Flora de México, A.C., Universidad Autónoma Metropolitana Iztapalapa y Comisión Nacional para el Conocimiento y Uso de la Biodiversidad. México, D.F. 116 pp.

Espejo, A. \& A. R. López-Ferrari. 1996b. Comentarios florístico-ecológicos sobre las iridáceas mexicanas. Acta Bot. Mex. 34: 25-47.

Espejo, A. \& A. R. López-Ferrari. 1997. Notas nomenclaturales sobre Iridaceae. Acta Bot. Mex. 41: 1-8.

Espejo, A., López-Ferrari, A. R. \& J. Ceja. 1998. Una nueva especie gipsófila de Sisyrinchium (Iridaceae: Sisyrinchieae) de México. Acta Bot. Mex. 44: 43-47.

Espejo, A., López-Ferrari, A. R. \& J. Ceja. 1999. Una nueva especie de Sisyrinchium (Iridaceae: Sisyrinchieae) del estado de Durango. Acta Bot. Mex. 49: 19-22.

Goldblatt, P. 1990. Phylogeny and classification of Iridaceae. Ann. Missouri Bot. Gard. 77: 607-627. Molseed, E. 1970. The genus Tigridia (Iridaceae) of Mexico and Central America. Univ. Calif. Publ. Bot. 54: 1-127. 